\title{
Rice Bran Makes a Healthy and Tasty Traditional Indonesian Goat Meatball, 'Bakso'
}

\author{
Rio Olympias Sujarwanta ${ }^{1,2,3, *} \oplus$, Michel Mubiayi Beya ${ }^{1} \oplus$, Desi Utami ${ }^{2,4} \oplus$, Jamhari Jamhari ${ }^{3}$, Edi Suryanto ${ }^{3} \oplus^{1}$, \\ Ali Agus ${ }^{5}$, Heather Eunice Smyth ${ }^{1} \mathbb{D}$ and Louwrens Christiaan Hoffman ${ }^{1,6} \mathbb{C}$
}

1 Centre for Nutrition and Food Sciences, Queensland Alliance for Agriculture and Food Innovation (QAAFI), The University of Queensland, Coopers Plains, Brisbane, QLD 4108, Australia; michel.beya@uqconnect.edu.au (M.M.B.); h.smyth@uq.edu.au (H.E.S.); louwrens.hoffman@uq.edu.au (L.C.H.)

2 School of Agriculture and Food Sciences, The University of Queensland, Gatton, QLD 4343, Australia; desi.utami@uq.net.au or desi.utami@ugm.ac.id

3 Department of Animal Products Technology, Faculty of Animal Science, Universitas Gadjah Mada, Yogyakarta 55281, Indonesia; jam_hari@ugm.ac.id (J.J.); edi_ugm@ugm.ac.id (E.S.)

4 Department of Agricultural Microbiology, Faculty of Agriculture, Universitas Gadjah Mada, Yogyakarta 55281, Indonesia

5 Department of Animal Nutrition and Feed Science, Faculty of Animal Science, Universitas Gadjah Mada, Yogyakarta 55281, Indonesia; aliagus@ugm.ac.id

6 Department of Animal Sciences, University of Stellenbosch, Private Bag X1, Matieland, Stellenbosch 7602, South Africa

check for updates

Citation: Sujarwanta, R.O.; Beya, M.M.; Utami, D.; Jamhari, J.; Suryanto, E.; Agus, A.; Smyth, H.E.; Hoffman, L.C. Rice Bran Makes a Healthy and Tasty Traditional Indonesian Goat Meatball, 'Bakso'. Foods 2021, 10, 1940. https:// doi.org/10.3390/foods 10081940

Academic Editors: Severiano R. Silva, Alfredo Jorge Costa Teixeira and Cristina Miranda Guedes

Received: 11 June 2021

Accepted: 29 July 2021

Published: 20 August 2021

Publisher's Note: MDPI stays neutral with regard to jurisdictional claims in published maps and institutional affiliations.

Copyright: (c) 2021 by the authors. Licensee MDPI, Basel, Switzerland. This article is an open access article distributed under the terms and conditions of the Creative Commons Attribution (CC BY) license (https:/ / creativecommons.org/licenses/by/ $4.0 /)$.
* Correspondence: rio.olympias.s@ugm.ac.id or r.sujarwanta@uq.edu.au

Abstract: Meatballs are popular in Asia and traditionally made from beef or chicken with tapioca $(\approx 8 \% w t / w t)$ as filler. Tapioca has a high glycaemic index $(\mathrm{GI})$; therefore, rice bran was evaluated as a substitute to create a healthier meatball of acceptable quality. Substitution of tapioca with rice bran (100:0; 75:25, 50:50; 25:75; 0:100\% tapioca: \% rice bran) decreased the starch content (7.8 to $3.3 \%$ ) and GI (56.08 to 43.85$)$ whilst increasing the protein (10.9 to $12.8 \%$ ) and fibre (8.1 to $10.3 \%$ ) contents. Although consistency ( 995 to $776 \mathrm{~N} / \mathrm{mm}$ ) was affected, firmness (90.6 to $90.5 \mathrm{~N}$ ) and shear force (300 to $312 \mathrm{~N}$ ) were only slightly affected by the ratio of tapioca to rice bran. Sensory analysis revealed that the goat meatball with the substitution of tapioca with up to $25 \%$ rice bran was deemed acceptable by 40 Indonesian consumers.

Keywords: rice bran; tapioca; goat; meatball; starch

\section{Introduction}

Meatballs are restructured meat products made from ground meat which is typically mixed with starch and some seasonings and formed into round balls (as big as a Ping-Pong ball) and boiled until well cooked [1]. This meatball is very popular among Asian consumers, including Indonesian consumers across all social classes [2]. A search on YouTube on 1 June 2021 with the keyword 'bakso', an Indonesian term for meatball, resulted in a hit on numerous videos on this food product; one of these had been watched at least 5.8 million times, indicating how popular this meat product is (https: / / www.youtube.com/watch?v=BJpGEtyVCII (accessed on 1 June 2021)). The meat products used for 'bakso' are either ground beef, buffalo, pork, goat, or poultry meat. The production of 'bakso' from goat is not as common as that from beef and chicken, even though, based on Meat and Livestock Australia's (MLA) latest report, the average goat meal in Indonesia places this country as the third-largest global consumer of goat meat [3]. Goat, as animal food, is recognised to be rich in protein containing little fat and cholesterol [4]. According to USDA [5], lean goat meat consists of about $75.4 \%$ moisture, $20.0 \%$ protein, $3.1 \%$ fat, and $1.1 \%$ ash-this indicates that goat has similar protein content to beef and 
chicken. Despite this fact, goat meat has a lower fat content which is only one-third of that of beef and less than half of chicken meat [5]. While for cholesterol, goat meat has been reported to have the lowest content $(75 \mathrm{mg})$, compared to chicken $(90 \mathrm{mg})$, or beef (86 per $100 \mathrm{~g}$ meat of cooked meat) [4]. Goat meat is, therefore, a healthier option, compared to other red meat groups; goat meat has the potential to substitute beef and chicken meat in the production of traditional 'bakso'.

Typically, 'bakso' are made from traditionally farmed species as protein sources, whilst tapioca is used as plant starch. The use of pork as the meat protein source is somewhat limited due to religious beliefs (Halal), and therefore, the use of alternative meat proteins such as goat meat is on the increase. An important ingredient of 'bakso' is cassava starchtypically used to produce a chewy sensation. However, the nutritional value of this starch is less desirable due to having a high content of carbohydrate $(87 \%)$ while being low in protein $(1.23 \%)$ and fibre $(0.2 \%)$, as reported by Ijioma [6]. Consumers are becoming increasingly aware of consuming a healthier diet as scientific reports on the relationship between diet and overweight-related diseases (e.g., diabetes) become more prevalent; colorectal cancer is also linked to a diet with too low an intake of fibre [7]. The obesity rate in the world in 2016 was over 650 million people, which could be found both in developing and developed countries [8]. In Indonesia, as a developing country, $21.8 \%$ of the adults are classed as being obese [9], while in a developed country such as Australia, 31\% of Australian adults were obese in 2017 [10]. Therefore, an exploration of a nutritional meal with lower fat, a lower glycaemic index, and high fibre is desirable to help global people lead a better life.

The glycaemic index (GI) for cassava starch is around 70 [11], while an alternative to this starch is rice bran, with a GI of 19 [12]. Rice bran, a by-product of the milling process, contains $11-15 \%$ crude protein, crude fat $15-19 \%$, and crude fibre $7-11 \%$ [13]. Indonesia is one of the three largest rice-producing nations globally, producing 56.54 million tons of milled rice in 2018 [14]. This resulted in 5.5 million tons/year of rice bran, a by-product of this milling process [15], which is generally only used for animal feed and not as a food source. It would be of great value if the use of this by-product can be upstreamed through which it becomes a sought-after product fit for human consumption rather than a low-value by-product traditionally used in animal nutrition. Rice bran is the cuticle between the paddy husk and rice grain produced during rice milling and commonly marketed as a cheap animal feed [16]. Rice bran contains high crude fibre, crude protein, zinc, iron, folic acid, and since it is a plant, it has no cholesterol. It is also known to have antioxidant compounds such as polyphenols, phytosterols, and vitamin B and is becoming more popular as a functional food. Even though studies of the nutritional value of rice bran have been conducted such as fermentation and functional rice bran [17], the utilisation of rice bran as a partial replacement of more traditional starch sources in goat meatballs ('bakso') is still absent. Rice bran has the potential to be a replacement for cassava starch due to its nutritional value and abundance. The objective of this research was to observe the effect of rice bran on the functional and consumer sensory quality of goat meatball when replacing the traditional starch source (tapioca).

\section{Materials and Methods}

\subsection{Raw Materials}

Goat meat trimmings derived from at least 30 carcasses slaughtered according to halal procedures were sourced from a commercial abattoir, vacuum packed, and stored frozen at $-20{ }^{\circ} \mathrm{C}$ until used. The proximate composition of the meat, rice bran, and tapioca as the base materials of this research are presented in Table 1. 
Table 1. Analysed proximate composition (\%) of goat meat, rice bran, and tapioca used to make goat meatballs ('bakso').

\begin{tabular}{ccccccc}
\hline Sample & Moisture & Ash & Protein & Fat & Fibre-NDF & Fibre-ADF \\
\hline Meat & $63.8 \pm 0.68$ & $0.9 \pm 0.02$ & $20.9 \pm 0.48$ & $11.8 \pm 1.50$ & ND $^{*}$ & ND * \\
Rice Bran & $7.5 \pm 0.00$ & $9.5 \pm 0.00$ & $13.6 \pm 0.00$ & $16.9 \pm 0.00$ & $28.8 \pm 1.05$ & $17.4 \pm 1.52$ \\
Tapioca & $10.8 \pm 0.00$ & $0.2 \pm 0.00$ & $0.00 \pm 0.00$ & $0.01 \pm 0.00$ & $3.7 \pm 1.15$ & $3.7 \pm 0.24$ \\
\hline * ND: not determined; NDF: neutral detergent fibre; ADF: acid detergent fibre. & &
\end{tabular}

\subsection{Meatball Preparation}

The basic ingredients (by weight) of the meatballs were ground goat meat $(56.3 \%)$, ice flakes $(22.5 \%)$, rice bran and/or tapioca starch $(8.1 \%), 6.7 \%$ eggs, $4.0 \%$ fried shallot, $1.4 \%$ salt, $0.6 \%$ sugar, $0.5 \%$ fried garlic, $0.4 \%$ agar powder, $0.3 \%$, and white pepper. The rice bran and tapioca starch were added in different ratios from $0 \%, 25 \%, 50 \%, 75 \%$, and $100 \%$ (Table 2). The five formulations based on the tapioca starch and rice bran compositions each had four replicates/batches weighing 1777g. Each replicate's ground meat was thawed overnight at $4{ }^{\circ} \mathrm{C}$. A half portion of ground meat was mixed with ground fried shallot and garlic using a Kenwood Major Premier food processor (DeLonghi Australia Pty Limited, NSW, Australia) for $1 \mathrm{~min}$ at speed 3. Into this mixture, the other half of the ground meat, salt, pepper, sugar, 2 eggs, agar, tapioca and/or rice bran, and crushed ice-water $(400 \mathrm{~g})$ were added and mixed thoroughly using the same processor for $3 \mathrm{~min}$ at speed 3 . From each formulation/treatment and batch/replicate, approximately $100 \mathrm{~g}$ raw meatballs were subsampled for chemical analysis. The remaining dough was then handmade (https: / / www.youtube.com/watch? $\mathrm{v}=$ BJpGEtyVCII (accessed on 10 January 2021)) into meatballs with a diameter of approximately $3 \mathrm{~cm}$ and a weight $\pm 20 \mathrm{~g}$. These meatballs were boiled in a water bath at an initial temperature of $100{ }^{\circ} \mathrm{C}$ for $5 \mathrm{~min}$ until all the meatballs floated and then drained for one minute. During the draining, the internal temperature of five meatballs for each replicate was measured.

Table 2. Recipe for goat 'bakso' meatballs with different ratios of tapioca starch to rice bran.

\begin{tabular}{cccccc}
\hline \multirow{2}{*}{ Ingredients (g) } & \multicolumn{5}{c}{ Starch: Rice Bran } \\
\cline { 2 - 6 } & $\mathbf{1 0 0 : 0}$ & $\mathbf{7 5 : 2 5}$ & $\mathbf{5 0 : 5 0}$ & $\mathbf{2 5 : 7 5}$ & $\mathbf{0 : 1 0 0}$ \\
\hline Ground goat meat & 1000 & 1000 & 1000 & 1000 & 1000 \\
Tapioca starch & 144 & 108 & 72 & 36 & 0 \\
Rice bran & 0 & 36 & 72 & 108 & 144 \\
Salt & 25 & 25 & 25 & 25 & 25 \\
Sugar & 10 & 10 & 10 & 10 & 10 \\
Fried garlic & 10 & 10 & 10 & 10 & 10 \\
Fried shallot & 55 & 55 & 55 & 55 & 55 \\
White pepper & 6 & 6 & 6 & 6 & 6 \\
Agar powder & 7 & 7 & 7 & 7 & 7 \\
Ice flakes & 400 & 400 & 400 & 400 & 400 \\
Egg & 120 & 120 & 120 & 120 & 120 \\
\hline Total & 1777 & 1777 & 1777 & 1777 & 1777 \\
\hline
\end{tabular}

\subsection{Chemical Analyses}

After cooking, five to six meatballs per replicate were collected and homogenised prior to chemical analyses. Each raw meatball batter's replicate was also homogenised further before chemical analyses. Moisture content was analysed following the AOAC (2012) [18] Official Method 934.01 by drying the samples in an oven for $48 \mathrm{~h}$ at $105^{\circ} \mathrm{C}$ and measuring the weight of the meatball before and after the water was removed. Ash content was observed by combustion of the moisture-free meatball samples at $550{ }^{\circ} \mathrm{C}$ in a furnace (Modutemp Pty. Ltd.; Perth, WA, Australia) for 8 h [19].

The neutral detergent fibre (NDF) was determined as follows: an empty filter bag (F57, Ankom Technology, New York, NY, USA) was weighed (W1). Moisture-free cooked meatball samples $(0.45-0.50 \mathrm{~g})$ were ground and placed into the weighed bag, and the 
weight thereof was recorded (W2). Each filter bag was heat-sealed completely (His, Ankom Technology, New York, NY, USA). All bags were placed into a container with $200 \mathrm{~mL}$ of acetone, shaken 10 times, and left to stand at room temperature for $10 \mathrm{~min}$. The acetone was discarded and replaced with new acetone, and the process was repeated. After removal of the acetone, the bags were air-dried before being placed on the bag suspender trays that were placed into the Ankom instrument (Ankom2000 with 65 rpm agitation, Ankom Technology, New York, NY, USA). A neutral detergent solution [made from $30 \mathrm{~g}$ of sodium dodecyl sulphate, $18.61 \mathrm{~g}$ of sodium borate, $4.56 \mathrm{~g}$ sodium phosphate dibasic (anhydrous), and $10.0 \mathrm{~mL}$ triethylene glycol to which $1 \mathrm{~L}$ of distilled water was added (2 L) was added into the digestion vessel, followed by $20 \mathrm{~g}$ of sodium sulphite and $4.0 \mathrm{~mL}$ of $\alpha$-amylase and the mixture incubated for $75 \mathrm{~min}$. When the digestion was completed, $2000 \mathrm{~mL}$ of boiled water was added to rinse the bags and $4.0 \mathrm{~mL}$ of $\alpha$-amylase was added. All sample bags were transferred into a $250 \mathrm{~mL}$ beaker with sufficient acetone and soaked for $5 \mathrm{~min}$, after which the bags were air-dried for $3 \mathrm{~h}$ and placed into an oven at $105^{\circ} \mathrm{C}$ to dry completely. The filter bags were removed and placed into a desiccator to allow cooling before weighing (W3). The blank bag correction was prepared as a running average of end oven-dried weight divided by the original blank bag weight which counted as $C 1$. The percentage of NDF was calculated according to the following:

$$
\frac{100 \times(\mathrm{W} 3-(\mathrm{W} 1 \times \mathrm{C} 1))}{\mathrm{W} 2}
$$

The method for analysing the acid detergent fibre (ADF) was similar to that for NDF; however, the reagents were changed. Acid detergent solution (20 g cetyl trimethylammonium bromide (CTAB) to $1 \mathrm{~L} 1.00 \mathrm{~N} \mathrm{H2SO} 4$ ) replaced the neutral detergent solution. Additionally, after completing the process, $4.0 \mathrm{~mL}$ of $\alpha$-amylase was not added during the rinsing process.

The starch contents of the meatball samples were determined as described by [20]. Briefly, $100 \mathrm{mg}$ ground sample was added into a tube to which $0.2 \mathrm{~mL}$ of $80 \%$ ethanol was mixed and the resulting mixture vortexed. Immediately thereafter, $3.0 \mathrm{~mL}$ of $\alpha$ amylase was added, followed by incubating the mixture for $6 \mathrm{~min}$ in a boiling water bath. At 2 and 4 min of incubation, samples were vortexed and returned to the water bath. After $6 \mathrm{~min}$, the samples were once more vortexed (Vortex Genie2, Scientific Industries, Palmerston North, New Zealand) and then transferred to a $50{ }^{\circ} \mathrm{C}$ water bath after adding $0.1 \mathrm{~mL}$ amyl glucosidase and incubated for $30 \mathrm{~min}$. The samples were then transferred to a $100 \mathrm{~mL}$ measuring flask, and the tube was rinsed using distilled water to make up the volume. A $2.0 \mathrm{~mL}$ sample was then removed and placed into a $10 \mathrm{~mL}$ centrifuge tube and centrifuged for $10 \mathrm{~min}$ at $3000 \mathrm{rpm}$; then, $0.2 \mathrm{~mL}$ of the clear suspension was placed into a new plastic tube, wherein $6 \mathrm{~mL}$ of glucose oxidase-peroxidase (GOPOD) reagent was added, and this mixture was incubated at $50{ }^{\circ} \mathrm{C}$ in a water bath for $20 \mathrm{~min}$; after the absorbance, it was measured at $510 \mathrm{~nm}$ (Shimadzu, UV-2550, Manassas, VA, USA).

Protein content was analysed using a LECO CN928 carbon/nitrogen combustion analyser (Leco, St Joseph, MI 49085, MI, USA). A $0.3 \mathrm{~g}$ defatted dry sample was combusted at a temperature of $1000{ }^{\circ} \mathrm{C}$. All samples were combusted on the same day. The crude protein content of the sample was estimated by multiplying the $\mathrm{N}$ content with a factor of 6.25 .

Fat content was analysed using chloroform-methanol, as described by Lee et al. (1996) [21]. A homogenised cooked meatball sample weighing $5.00 \mathrm{~g}$ was placed into a $100 \mathrm{~mL}$ beaker. Exactly $40 \mathrm{~mL}$ chloroform/methanol (2:1) was added to the sample and stirred for one minute. The mixture was filtered through a Whatman \#4 filter paper into a separation funnel. An additional $10 \mathrm{~mL}$ of chloroform/methanol (2:1) was used to rinse the beaker and filter paper. Into a separation funnel, $20 \mathrm{~mL}$ of $5 \% \mathrm{NaCl}$ was added and mixed thoroughly before allowing the mixture to stand for 30-60 min until the separation line was visible. Exactly $5 \mathrm{~mL}$ of the bottom layer was collected into a preweighed beaker, dried in a fume cupboard, and weighed. 


\subsection{Physical Analyses}

The Hamm press method was used to measure the water holding capacity of the meatballs. From the homogenised cooked meatballs, $0.3 \mathrm{~g}$ from each sample was placed onto the centre of a labelled filter paper disc. The sample was then pressed between Perspex plates (standard pressure: $588 \mathrm{~N}$ ) using a leverage locking system for exactly $60 \mathrm{~s}$, and a digital photograph of each sample showing seepage liquid and squashed meatball areas were taken. The drip area was calculated using ImageJ software (http:/ / rsbweb.nih.gov/ij/ (accessed on 8 September 2020)) by calculating the outer area minus the inner area. The WHC was calculated using the following equation [22]:

$$
\text { WHC }: 1-\frac{\text { meat area }}{\text { spread of juice area }}
$$

Measurements of meatballs' texture were performed on a computer-assisted texture analyser (Lloyd TA1, Instruments, Bognor Regis, West Sussex, UK) equipped with a $250 \mathrm{~N}$ load cell. The settings of the equipment for the first test (measuring consistency and firmness) were as follows: preload at a speed of $21 \mathrm{~mm} / \mathrm{min}$; a test speed of $100 \mathrm{~mm} / \mathrm{min}$; distance (compression) travelled $=50 \%$; preload stress of $5.6 \mathrm{~N}$. Consistency was defined as the total energy per unit distance (work) used for the $50 \%$ compression and firmness as the maximum amount of energy required to distort the meatball at $50 \%$ compression. For the second measurement, the shear force required to shear through the whole meatball at a speed of $100 \mathrm{~mm} / \mathrm{min}$ was determined. Cooked meatball samples were stored overnight in refrigeration condition at $<5^{\circ} \mathrm{C}$. Thereafter, the samples were maintained at room temperature for $1 \mathrm{~h}$ prior to the textural analysis [23]. Five samples for each treatment's replicate were evaluated for each of the two assessments performed to compare the meatballs texture analysis: first, a single one-bite was performed to determine consistency and firmness using a compression plate with $100 \mathrm{~mm}$ diameter. Second, a shear test was performed using a V-shaped blade to calculate the shear force required to cut through the sample [24].

Colour measurement was carried out as described by Erdem et al. (2020) [25], with modification, using a chromameter (CR-400/4310 Thermo Fisher Scientific Australia Pty Ltd., 5 Caribbean Drive, Scoresby, VIC 3179, Australia) set at d:0 $0^{\circ}$ (diffuse illumination/ $0^{\circ}$ viewing angle; specular component included) with a standard observer angle of CIE: $2^{\circ}$ and illuminate/observer angle: D-65/10. The chromameter was placed on a white tile to calibrate as per the supplier's instructions [24]. Cooked samples were stored overnight in refrigeration condition at $<5{ }^{\circ} \mathrm{C}$. Five samples for each treatment's replicate were crosssectioned, and the colour measurement was taken at the core. The colour reading includes lightness (L), redness (a), and yellowness (b). Average colour values were calculated from five samples per replicate.

Water activity was measured using a water activity metre (Lab Touch-aw, Novasina AG, Lachen, Switzerland) at room temperature [26].

\subsection{Glycaemic Index Estimation}

The estimation of the glycaemic index (GI) value of the 'bakso' meatballs used the Formula (a), as described by William et al. [27]. To obtain the GI, the carbohydrate content of each ingredient in the recipe was determined. The carbohydrate values of the ingredients were obtained from a food nutrition database [28]. In order to quantify the amount of carbohydrate each ingredient contributed to the meatball recipe, the total grams of carbohydrate were divided by the gram contributed by that ingredient, and then the proportion for the components was multiplied by the standard GI of the component as obtained from the nutrition database [28]. The GI for agar was obtained from [29]. The calculated GI values from each component were then summed to obtain the total GI of the meatball. The calculation of GI was as follows: 
(a) Food GI $=\{[$ GIfood $a \times g$ available carbohydrate food $a]+[$ GI food $b \times g$ available carbohydrate food $b]+$

[GI food $c \times g$ available carbohydrate food $c]+\ldots$ \}/total $g$ available carbohydrate

\subsection{Consumer Sensory Evaluation}

This research was approved by the University of Queensland's Human Research Ethics Committee (HREA ethics approval number 2020001685). To evaluate consumer acceptance of the goat meatball with the addition of rice bran, 40 Australian-based Indonesian participants were recruited locally both in Gatton and St. Lucia, Queensland, who were regular consumers of meatballs, both previously when living in Indonesia and now in Australia. To reach the participants, an Indonesian community WhatsApp group exists (in which two of the coinvestigators participate) that was enabled to communicate with the members. Consumers were aged between 20 and 60, with an average of 35 years old, there were 23 male and 17 female participants. The general demographic profile of the 40 Indonesian consumers is shown in Table 3.

Table 3. General demographic profiles of the Indonesian consumers evaluating goat 'bakso' meatballs made with varying levels of rice bran substituted for tapioca.

\begin{tabular}{|c|c|c|c|c|c|c|c|c|c|}
\hline Gender & $\%$ & Age & $\%$ & $\begin{array}{c}\text { Household } \\
\text { Income } \\
\text { (AUD/month) }\end{array}$ & $\%$ & $\begin{array}{c}\text { Number of } \\
\text { People in } \\
\text { Household }\end{array}$ & $\%$ & $\begin{array}{l}\text { Education } \\
\text { Level }\end{array}$ & $\%$ \\
\hline Male & 57.5 & 20 or younger & 2.5 & Below 2000 & 22.5 & 1 & 10 & Bachelor & 30 \\
\hline \multirow{5}{*}{ Female } & 42.5 & $21-30$ & 37.5 & 2001-3000 & 47.5 & 2 & 20 & Master & 30 \\
\hline & & $31-40$ & 52.5 & $3001-4000$ & 25 & 3 & 20 & Doctoral & 40 \\
\hline & & $41-50$ & 2.5 & $4001-5000$ & 5 & 4 & 45 & Post-doctoral & 0 \\
\hline & & $51-60$ & 2.5 & $5001-10,000$ & & 5 & 2.5 & & \\
\hline & & 60 years or older & 2.5 & 10,000 or more & & 6 or more & 2.5 & & \\
\hline Total (\%) & 100 & & 100 & & 100 & & 100 & & 100 \\
\hline
\end{tabular}

Two sessions were held at The University of Queensland (UQ) each at the St Lucia Campus and Gatton Campus' using a 'board room' style setup; both sessions were from the Indonesian student community, and no participant partook in both sessions. Participants were asked to attend one $1 \mathrm{~h}$ session and tasted no more than 10 meatballs during the session. During sessions, participants were asked to provide informed consent and provided instructions on the session format and consumer questionnaire. Participants were informed to consume as much or as little as they wished of each meatball to complete their assessment. Participants were provided morning tea as an incentive for their participation.

The 40 consumers were divided into groups of 8 , with each group receiving a different replicate of each treatment. Participants were asked to score the sample for acceptability of flavour, colour, juiciness, texture, taste, and overall palatability using a 9-point hedonic scale, where 8 is 'like extremely', 7 is 'like very much', 6 is 'like moderately', 5 is 'like slightly', 4 is 'neither like nor dislike', 3 is 'dislike slightly', 2 is 'dislike moderately' and, 0 is 'dislike extremely'. In addition, participants were also provided a detailed demographics questionnaire (age, gender, household income, number or persons in household, and education level) and a line of questions related to protein consumption behaviour.

Prepared meatballs were consumed within three days of preparation. Meatballs were removed from cold storage $\left(4^{\circ} \mathrm{C}\right)$ at least $60 \mathrm{~min}$ prior to heating for evaluation. The meatballs were served warm by reheating in a microwave (Homemaker, $900 \mathrm{~W}$ ) for $60 \mathrm{~s}$ and presented immediately (within $5 \mathrm{~min}$ of heating). Individual randomly numbered single meatball samples (approx. $20 \mathrm{~g}$ per serving after reheating) were presented to consumers on a plastic plate together with a plastic fork, whilst filtered water for refreshing the palate between samples was also provided. Replicates from all five different sample treatments were presented to consumers according to a randomised design, with at least 2 min between each sample. In total, each replicate from each treatment was evaluated by 20 consumers. 


\subsection{Statistical Analysis}

The experiment was carried out with five treatments, each with four replications. The data obtained from chemical analysis (moisture, ash, protein, fat, fibre-NDF, and fibre-ADF), and physical analysis (raw meatball weight, cooked meatball weight, meatball temperature, consistency, firmness, shear force, colour, water activity water holding capacity) were analysed by one-way analysis of variance (ANOVA) in Statistica ${ }^{\circledR}$ 13.5.0.17 (TIBCO ${ }^{\text {TM }}$ Software inc. http:/ / tibco.com (accessed on 26 October 2020)). For post hoc analysis, Fisher's least significant difference (LSD) test was utilised. For the sensory analyses (overall, flavour, colour, juiciness, texture, taste, and odour), a mixed model ANOVA with panellist and session as random effects, and treatment as a fixed effect, were conducted on the R package (lmerTest's version 3.1-3; https:/ / github.com/runehaubo/lmerTestR (accessed on 26 October 2020)). Main effects and interactions with a $p \leq 0.05$ are reported as significant. Principal component analysis (PCA) was performed to study the relationship between chemical characteristics and physical properties.

\section{Results}

The proximate composition of the basic ingredients used to make the goat meatballs and the general demographic profile of the Indonesian consumers are shown in Tables 1 and 3, whilst Figures 1 and 2 report the protein consumption profile and meatball consumption frequency of our participants, respectively. The statistical analysis results of the chemical analysis, physical analysis, and sensory analysis for meatball substituted by various levels of rice bran are presented in Table 4 . Goat meat contained up to $20.9 \%$ protein with a fat content of $11.8 \%$, while the rice bran had $13.6 \%$ protein, $16.9 \%$ fat content, and fibre-NDF of $28.8 \%$, and fibre-ADF of $17.4 \%$. Tapioca had no protein and fat, whilst both fibre-NDF and ADF were $<4.0 \%$.

The weight of raw meatballs did not differ between the five treatments; however, after being boiled, the weights differed $(p=0.05$; Table 4$)$. When tapioca was fully replaced $(100 \%)$ with rice bran, the average boiled meatball weights were the lightest. The temperatures of the different meatball treatments after boiling did not differ $(p=0.72)$. The moisture contents of the raw dough did not differ between the treatments. In contrast, the moisture in the cooked meatball decreased as the level of rice bran increased $(p=0.01)$. Treatment influenced the protein contents of both the raw and cooked meatballs. Although the protein content varied between the ratio of tapioca and rice bran $(p=0.02)$, the two treatments with the higher levels of tapioca had lower protein contents that did not differ from each other (11.6-11.9\%) than the higher-level rice-bran-containing treatments (13.5-14.4\%), the latter not differing from each other. It was reported that adding rice bran to the fermented cereal-based food product also increased the protein content significantly [30].

Fat content ranged from 8 to $11 \%$ in the cooked meatballs; however, it did not differ both in the raw $(p=0.67)$ and cooked $(p=0.15)$ meatballs. Ash contents in both raw and cooked meatballs increased with decreasing levels of tapioca. The substitution of rice bran decreased the amount of starch considerably $(p<0.01)$, which ranged from $7.8 \%$ in the $0 \%$ rice bran treatment to $3.3 \%$ in $100 \%$ rice bran meatballs. The fibre-NDF and -ADF also varied among the treatments $(p=0.10)$, with a slight rise with the addition of rice bran from $35.7 \%$ to $38.3 \%$ for fibre-NDF and $8.1 \% 4$ to $10.4 \%$ for fibre-ADF.

The calculation of GI values resulting from the replacement of tapioca starch by rice was 56.08 for $0 \%, 53.49$ for $25 \%, 50.62$ for $50 \%, 47.42$, for $75 \%$, and 43.85 for $100 \%$ rice replacement, respectively. As indicated in Table $4,100 \%$ of rice bran substitution showed the highest water holding capacity (WHC) $(p<0.01)$; as the amount of rice bran added decreased, the WHC also decreased. The water activity also decreased with an increase in rice bran $(p=0.01)$; this would indicate that the products with high bran \% should be more microbial shelf stable. The texture analysis results are presented in Table 4 . The consistency $(p=0.01)$ and firmness $(p=0.01)$ parameters differed between the treatments. The consistency $(\mathrm{N} / \mathrm{mm})$ decreased as the rice bran substitution increased; however, the firmness $(\mathrm{N})$ indicated inconsistent results, as the treatment of $50 \%$ rice bran showed the 
highest firmness, while the lowest firmness was found in the $100 \%$ substitution by rice bran. The shear force $(\mathrm{N})(p>0.05)$ did not differ between treatments.

Table 4. Mean ( \pm s.e.) chemical, physical, and sensory values for goat meatballs made with varying ratios of tapioca and rice bran.

\begin{tabular}{|c|c|c|c|c|c|c|}
\hline \multirow{2}{*}{ Parameter } & \multicolumn{5}{|c|}{ Tapioca to Rice Bran Ratio } & \multirow[b]{2}{*}{$p$-Value } \\
\hline & 100:0 & $75: 25$ & $50: 50$ & $25: 75$ & $0: 100$ & \\
\hline \multicolumn{7}{|l|}{ Chemical Analysis } \\
\hline Weight (raw) g & $1338.4 \pm 9.74$ & $1268.1 \pm 84.32$ & $1338.5 \pm 11.68$ & $13,481.3 \pm 19.31$ & $1329.2 \pm 15.08$ & \\
\hline Weight (cooked) g & $1393.1^{\mathrm{a}} \pm 15.76$ & $1291.4^{\mathrm{ab}} \pm 86.55$ & $1346.6^{\mathrm{a}} \pm 81.71$ & $1325.3^{\mathrm{ab}} \pm 18.71$ & $1220.0^{b} \pm 14.66$ & 0.99 \\
\hline $\begin{array}{c}\text { Temperature of } \\
\text { meatball }{ }^{\circ} \mathrm{C}\end{array}$ & $78.1 \pm 1.78$ & $78.7 \pm 0.98$ & $76.5 \pm 3.61$ & $78.3 \pm 0.73$ & $81.3 \pm 1.84$ & 0.05 \\
\hline Moisture (raw) (\%) & $64.0 \pm 0.56$ & $64.1 \pm 0.48$ & $65.2 \pm 0.46$ & $65.2 \pm 0.74$ & $64.3 \pm 0.10$ & 0.72 \\
\hline Moisture (cooked) (\%) & $66.9^{\mathrm{a}} \pm 0.48$ & $65.2^{\mathrm{b}} \pm 0.71$ & $65.1^{b} \pm 0.68$ & $64.9^{b} \pm 0.51$ & $63.2^{\mathrm{c}} \pm 0.09$ & 0.35 \\
\hline Protein (raw) $(\%)$ & $10.9^{b} \pm 0.11$ & $11.2^{b} \pm 0.59$ & $11.8^{\mathrm{ab}} \pm 0.58$ & $11.7^{\mathrm{ab}} \pm 0.23$ & $12.8^{\mathrm{a}} \pm 0.05$ & $<0.010$ \\
\hline Protein (cooked) $(\%)$ & $11.9^{b} \pm 0.62$ & $11.6^{\mathrm{b}} \pm 0.24$ & $13.5^{\mathrm{a}} \pm 0.44$ & $13.5^{\mathrm{a}} \pm 0.41$ & $14.4^{\mathrm{a}} \pm 0.43$ & 0.07 \\
\hline Fat (raw) $(\%)$ & $10.5 \pm 0.77$ & $12.5 \pm 1.11$ & $11.0 \pm 1.47$ & $12.5 \pm 0.77$ & $11.1 \pm 0.87$ & 0.02 \\
\hline Fat (cooked) (\%) & $8.7 \pm 0.46$ & $10.1 \pm 0.56$ & $10.1 \pm 0.56$ & $10.2 \pm 0.72$ & $10.9 \pm 0.75$ & 0.67 \\
\hline Fibre-NDF (DM \%) & $35.7 \pm 0.64$ & $37.6 \pm 1.59$ & $37.3 \pm 1.73$ & $41.2 \pm 1.54$ & $38.3 \pm 0.75$ & 0.15 \\
\hline Fibre-ADF (DM \%) & $8.1 \pm 0.64$ & $8.6 \pm 0.29$ & $9.2 \pm 0.86$ & $10.4 \pm 0.96$ & $10.3 \pm 0.75$ & 0.1 \\
\hline Starch (cooked) & $7.8^{\mathrm{a}} \pm 1.31$ & $7.8^{\mathrm{a}} \pm 0.11$ & $6.2^{\mathrm{ab}} \pm 0.06$ & $5.0^{b c} \pm 0.23$ & $3.3^{c} \pm 0.08$ & 0.1 \\
\hline Ash (raw) (\%) & $2.0^{\mathrm{d}} \pm 0.04$ & $2.1^{c} \pm 0.03$ & $2.3^{\mathrm{b}} \pm 0.05$ & $2.4^{b} \pm 0.05$ & $2.6^{\mathrm{a}} \pm 0.05$ & 0.01 \\
\hline Ash (cooked) (\%) & $1.6^{\mathrm{d}} \pm 0.04$ & $1.7^{\mathrm{d}} \pm 0.05$ & $1.9^{c} \pm 0.03$ & $2.0^{b} \pm 0.00$ & $2.3^{a} \pm 0.03$ & $<0.010$ \\
\hline \multicolumn{7}{|l|}{ Physical analysis } \\
\hline Consistency (N/mm) & $99.5^{\mathrm{a}} \pm 3.59$ & $87.7^{b} \pm 3.76$ & $71.6^{c} \pm 5.20$ & $75.7^{c} \pm 3.52$ & $77.6^{b c} \pm 2.68$ & 0.01 \\
\hline Firmness $(\mathrm{N})$ & $9.0^{\mathrm{b}} \pm 0.02$ & $9.1^{\mathrm{a}} \pm 0.02$ & $9.2^{\mathrm{a}} \pm 0.03$ & $9.1^{b} \pm 0.05$ & $9.1^{\mathrm{b}} \pm 0.00$ & 0.01 \\
\hline Shear Force $(\mathrm{N})$ & $30.0^{\mathrm{ab}} \pm 1.62$ & $27.8^{\mathrm{abc}} \pm 1.22$ & $26.4^{b c} \pm 1.56$ & $25.8^{c} \pm 1.34$ & $31.2^{\mathrm{a}} \pm 1.06$ & 0.06 \\
\hline $\mathrm{L}^{*}$ & $47.0^{\mathrm{c}} \pm 0.77$ & $47.4^{\mathrm{bc}} \pm 0.31$ & $49.2^{\mathrm{a}} \pm 0.41$ & $49.0^{\mathrm{ab}} \pm 0.85$ & $48.7^{\mathrm{abc}} \pm 0.34$ & 0.11 \\
\hline$a^{*}$ & $1.6^{\mathrm{a} \pm} 0.15$ & $1.2^{\mathrm{ab}} \pm 0.22$ & $0.8^{\mathrm{b}} \pm 0.21$ & $0.7^{\mathrm{b}} \pm 0.11$ & $0.8^{b} \pm 0.23$ & 0.04 \\
\hline$b^{*}$ & $11.5^{\mathrm{b}} \pm 0.26$ & $11.8^{\mathrm{b}} \pm 0.26$ & $13.7^{\mathrm{a}} \pm 0.24$ & $13.4^{\mathrm{a}} \pm 0.53$ & $14.1^{\mathrm{a}} \pm 0.18$ & $<0.010$ \\
\hline Aw & $0.984^{\mathrm{a}} \pm 0.0015$ & $0.983^{\mathrm{ab}} \pm 0.0015$ & $0.982^{\mathrm{ab}} \pm 0.0015$ & $0.979^{b c} \pm 0.0015$ & $0.975^{c} \pm 0.0015$ & 0.01 \\
\hline $\begin{array}{l}\text { Water Holding Capacity } \\
\text { Sensory analysis }\end{array}$ & $0.02^{\mathrm{d}} \pm 0.020$ & $0.08^{\mathrm{cd}} \pm 0.020$ & $0.13^{b c} \pm 0.020$ & $0.16^{\mathrm{b}} \pm 0.0120$ & $0.24^{\mathrm{a}} \pm 0.020$ & $<0.010$ \\
\hline Overall & $6.5^{\mathrm{a}} \pm 0.15$ & $6.4^{\mathrm{a}} \pm 0.15$ & $6.1^{\mathrm{ab}} \pm 0.14$ & $5.8^{b} \pm 0.19$ & $5.7^{\mathrm{b}} \pm 0.20$ & $<0.010$ \\
\hline Flavour & $6.3^{a} \pm 0.19$ & $6.2^{\mathrm{a}} \pm 0.18$ & $5.9^{\mathrm{ab}} \pm 0.15$ & $5.7^{b} \pm 0.18$ & $5.7^{b} \pm 0.19$ & 0.03 \\
\hline Colour & $6.0 \pm 0.20$ & $6.3 \pm 0.18$ & $6.2 \pm 0.17$ & $6.0 \pm 0.19$ & $5.8 \pm 0.19$ & 0.21 \\
\hline Juiciness & $5.8^{\mathrm{a}} \pm 0.15$ & $5.9^{\mathrm{ab}} \pm 0.16$ & $6.1^{\mathrm{a}} \pm 0.17$ & $5.4^{b c} \pm 0.20$ & $5.2^{\mathrm{c}} \pm 0.27$ & $<0.010$ \\
\hline Texture & $6.1^{\mathrm{a}} \pm 1.16$ & $5.7^{\mathrm{ab}} \pm 0.23$ & $5.4^{b c} \pm 0.20$ & $5.5^{b c} \pm 0.23$ & $5.2^{c} \pm 0.25$ & $<0.010$ \\
\hline Taste & $6.2^{\mathrm{a}} \pm 0.20$ & $6.2^{\mathrm{a}} \pm 0.14$ & $6.0^{\mathrm{ab}} \pm 0.18$ & $5.8^{\mathrm{ab}} \pm 0.22$ & $5.5^{b} \pm 0.20$ & 0.02 \\
\hline Odour & $6.1 \pm 0.22$ & $6.1 \pm 0.16$ & $5.9 \pm 0.18$ & $6.0 \pm 0.20$ & $5.6 \pm 0.15$ & 0.15 \\
\hline
\end{tabular}

All values are expresses as mean \pm standard error for chemical, physical analysis, and sensory analysis. a,b,c,d Means with different superscript letters in the same row differ significantly $(p \leq 0.05)$. NDF: neutral detergent fibre, ADF: acid detergent fibre, DM: dry matter.

The $L^{*}$ (lightness) values of the treatment without rice bran replacement was the lowest $(p=0.11)$, compared to other treatments; however, there was no fixed trend noticeable. The effect of rice bran substitution on $a^{*}$ (redness) values of the goat meatball differed $(p=0.04)$, although the values' differences were numerically minimal. The $\mathrm{b}^{*}$ (blue to yellow) values differed among the treatments $(p<0.01)$, increasing as the rice bran substitution increased. The substitution by rice bran showed varying effects on the sensory properties as indicated by the Indonesian consumers. The consumer acceptance scores of colour $(p=0.21)$ and odour $(p=0.15)$ did not differ between the treatments of various ratios of starch to rice bran. The flavour $(p=0.03)$, juiciness $(p<0.01)$ and texture attributes showed similar results; the ratio of rice bran substitution from $75 \%$ to $100 \%$ were rated lower. Juiciness showed unexpected results $(p<0.01)$, where consumers gave a higher score on the $50 \%$ of rice bran substitution rather than $0 \%$ and $25 \%$. The texture attribute decreased $(p<0.01)$ as the amount of rice bran substitution increased. The 'overall' attribute differed amongst the treatments $(p<0.01)$; however, the substitution of rice bran up to $50 \%$ did not affect the 'overall' consumer acceptance scores, whereas a higher \% substitution led to a decreased score. 
Protein consumption profiles for each Indonesian participant is displayed in Figure 1, with six categories of protein source-beef, chicken, fish, goat, pork, and soybean product. Beef product was the most widely consumed protein source, followed by chicken, while pork was rarely consumed. More than $70 \%$ of participants consumed beef more than three times a week; in contrast, more than $70 \%$ of the participants surveyed have never eaten pork as their protein source. Lamb or goat meat consumption was also very low- $62.5 \%$ of consumers stated that they rarely consumed this protein source.

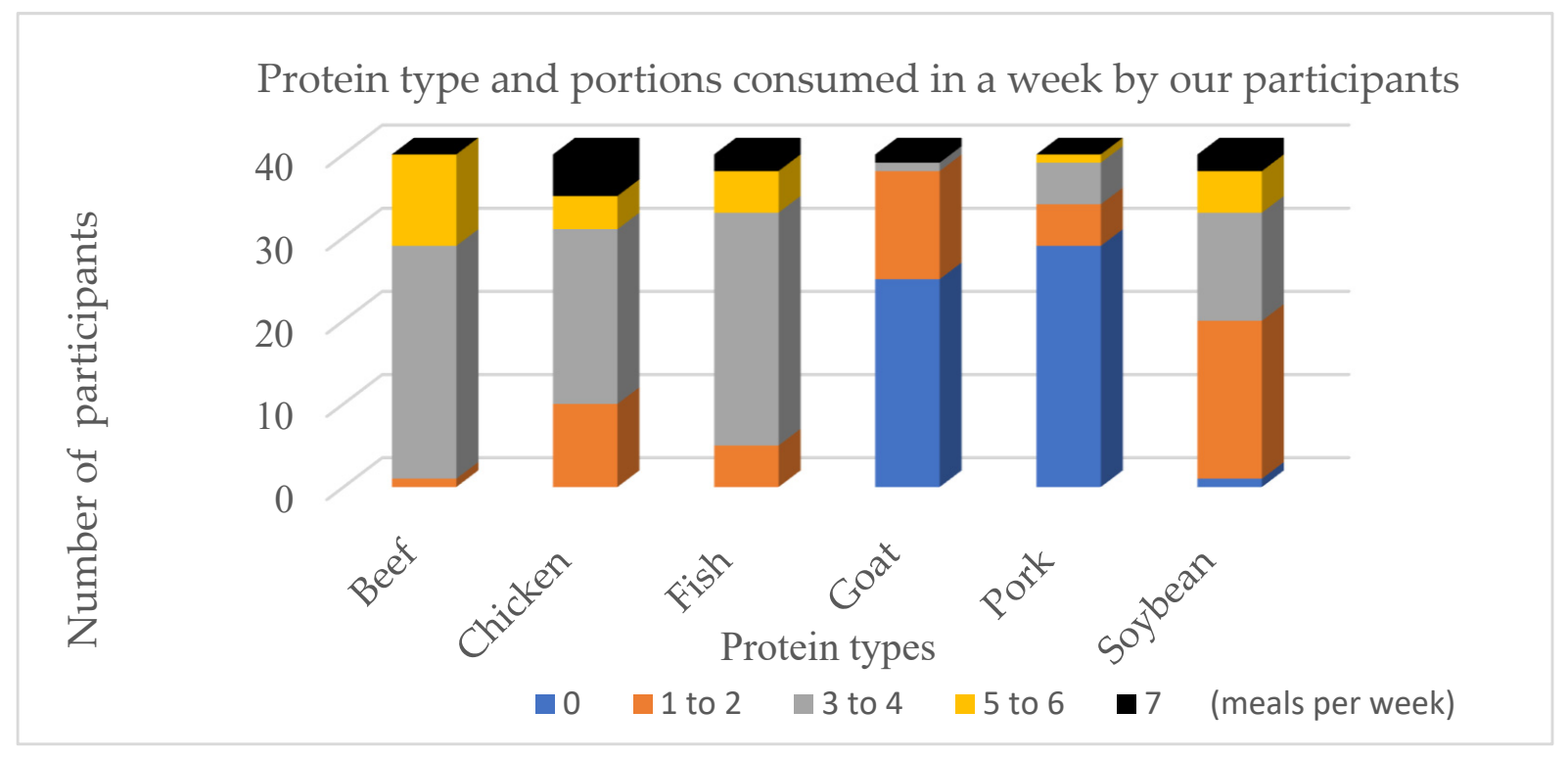

Figure 1. Protein source types and frequency of its consumption by 40 participants. Protein sources including beef, chicken, fish, goat, pork, and soybean, and frequency meals per week including $0,1-2,3-4,5-6$, and 7 times per week.

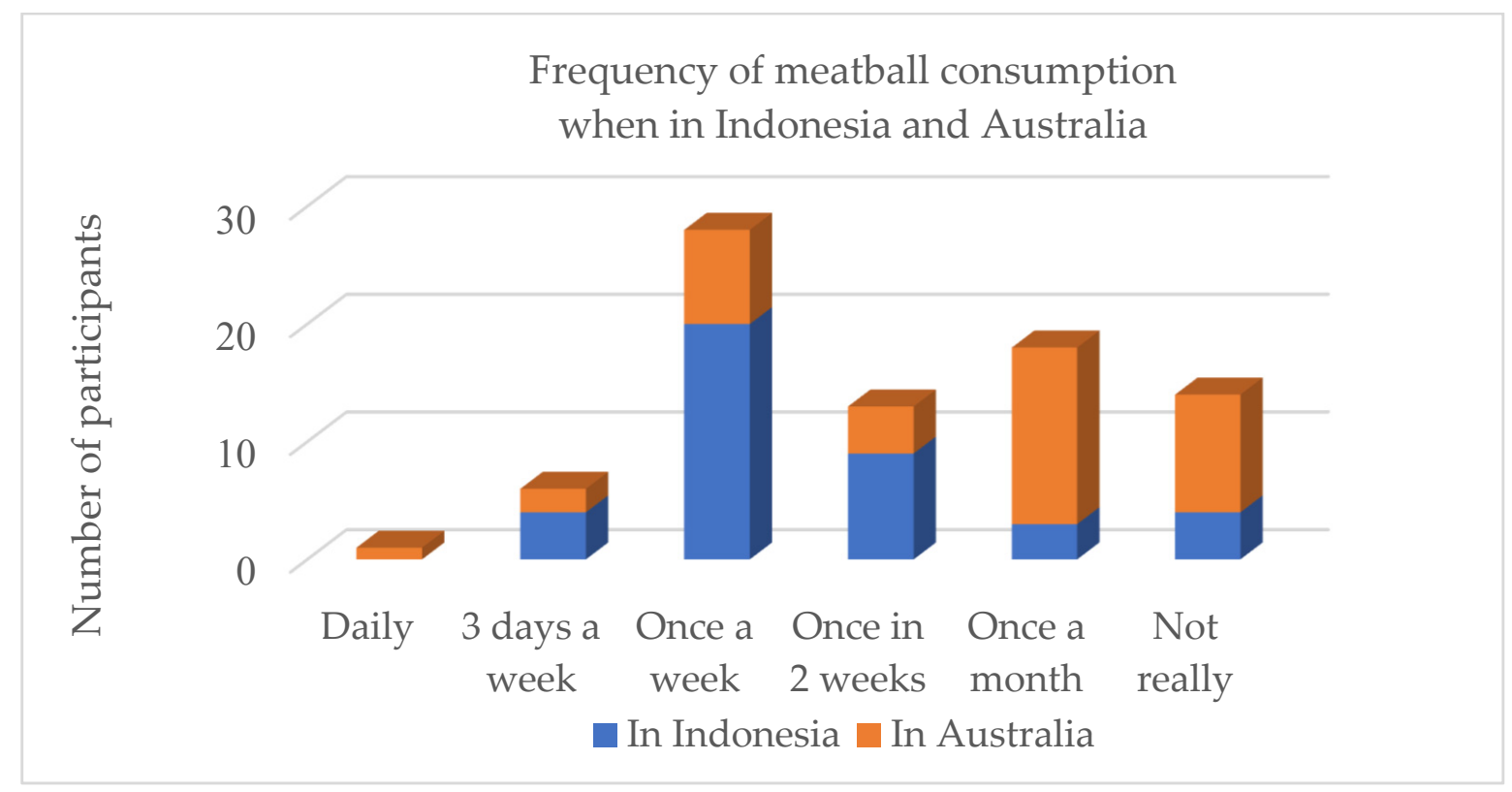

Figure 2. Frequency of meatball consumption both when stay in Indonesia and Australia of our participants, i.e., 40 Indonesians who currently reside in Australia.

Meatball consumption behaviour, both in Indonesia and Australia, was also part of the consumer questionnaire. Most participants $(60 \%)$ consumed meatballs at least once a week while in Indonesia, and more than $25 \%$ of them consumed meatballs in Australia once a week, indicating that meatballs are very popular among the participants (Figure 2). 
Principal component analysis (PCA) biplot demonstrates the means of the relationship between chemical properties and physical characteristics of goat meatball substituted by the five rice bran treatments (A: $0 \%$ rice bran; $\mathrm{B}: 25 \%$ rice bran; $\mathrm{C}: 50 \%$ rice bran; $\mathrm{D}: 75 \%$ rice bran and E: $100 \%$ rice bran) (Figure 3) and indicated that the control treatment (without substitution of rice bran) showed a stronger association with the consistency and $\mathrm{a}^{*}$ colour ordinate than the other treatments. The B treatment showed a stronger relationship with water activity and moisture of cooked meatballs. The $C$ treatment with $50 \%$ starch and rice bran indicated stronger relationships with fibre-NDF, fibre-ADF, protein content, and moisture content. The $75 \%$ replacement of tapioca with rice bran (D treatment) had a close relationship with $\mathrm{L}^{*}$, fibre-NDF, fibre-ADF, protein content, and ash content. Surprisingly, treatment with $100 \%$ substitution of rice bran showed stronger relationships between protein content, fibre-NDF, fibre-ADF, WHC, ash content, and shear force.

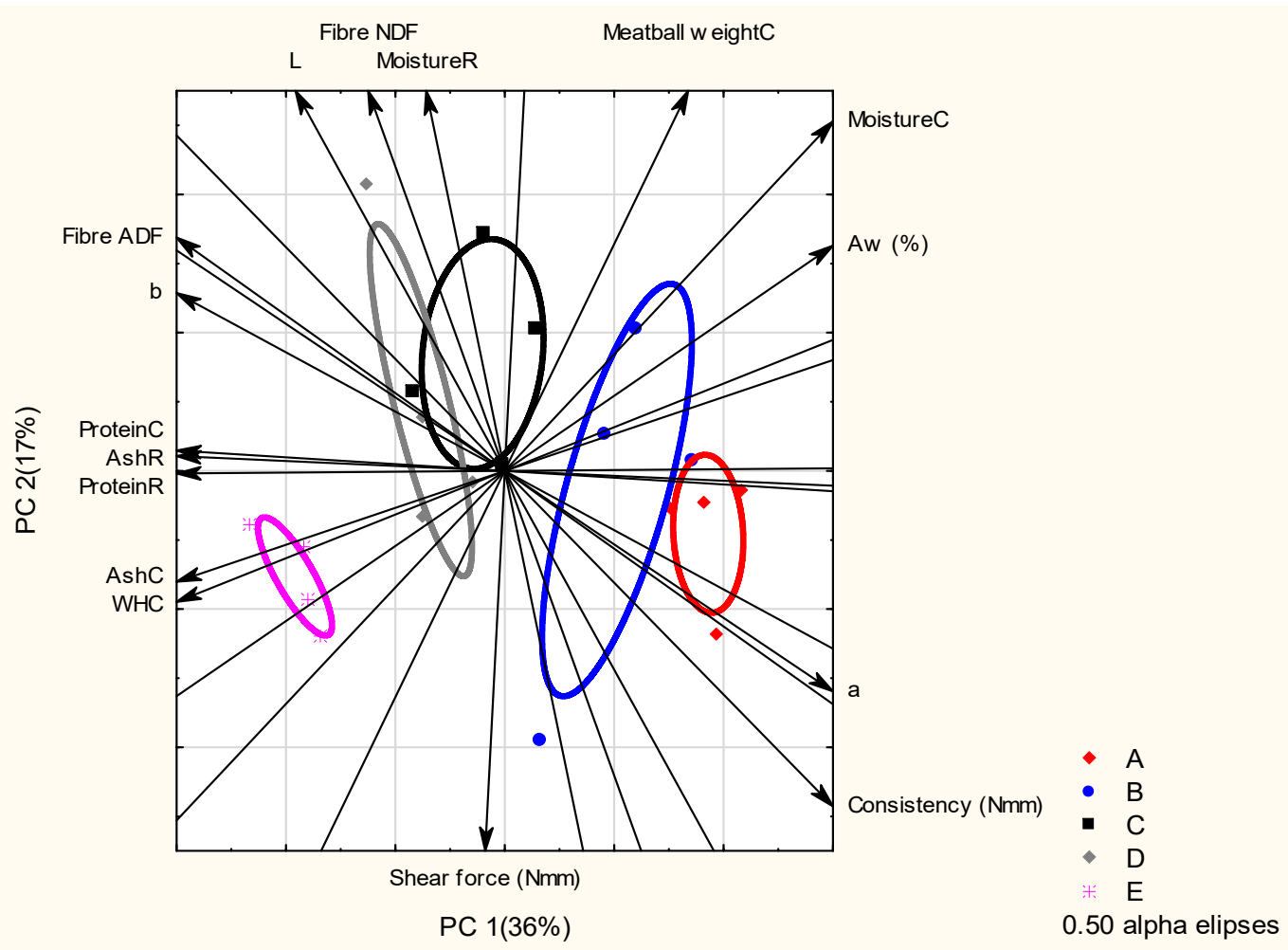

Figure 3. Principal component analysis (PCA) biplot indicating the means of the associations between chemical characteristics and physical properties of five treatments of tapioca substituted with rice bran: $\mathrm{A}=$ starch: rice bran (100:0); $\mathrm{B}=$ starch: rice bran (75:25); $\mathrm{C}=$ starch: rice bran (50:50); $\mathrm{D}=$ starch: rice bran (25:75); E = starch: rice bran (100:0).

\section{Discussion}

\subsection{Chemical Analysis}

Typically, the fat content of goat meat ranges between 1.13 and $2.39 \%$ (supplemented with grass hay and sunflower cake) [31]; generally, goat meat is lean with lower levels of subcutaneous fat [32]. The goat meat fat in this experiment was high (11.8\%; Table 1$)$ as trimming cuts that contained a reasonable amount of visible fat were used; therefore, it was decided to make the goat meatballs without any additional fat added.

There were no major differences among the goat meatball samples in terms of temperature, raw meatball weight, fat in both raw and cooked samples, moisture in cooked meatball, and fibre-NDF and -ADF (Table 4). The moisture content in the boiled/cooked meatball decreased as the replacement of rice bran increased. However, this loss in moisture would most probably be negated when the meatballs are consumed with soy and chili sauces-a typical way of eating 'bakso' as a meal in Asia. The protein content in 
the cooked meatball increased with the addition of rice bran; this increase is directly linked to the protein content of the rice bran, whilst the tapioca had no measurable protein (Table 1). In contrast, the addition of $1-4 \%$ of dietary fibre from rice bran decreased the protein content of emulsion-type sausages [33]. During the boiling/cooking process, the meatballs lost $\sim 2 \%$ fat, a loss linked to the fat melting/leaching out during the cooking process. It was noted that an increase in total cooking loss was linked to a decrease in goat meat's fat content [34]

As expected, the addition of rice bran increased the fibre content of the meatballs (Table 4); the ADF-fibre content was $27 \%$ higher in the meatball with $100 \%$ rice bran and $17 \%$ higher in fibre-NDF in tapioca:rice bran (with the ratio of $25: 75 \%$ ) than the $100 \%$ tapioca treatment. However, the total contribution of the tapioca and/or rice bran to the recipe was only $8.1 \%$; thus, the reason for the slight change in both ADF and NDF \% is depicted in Table 4. In contrast, the starch content decreased with the increase in the percentage of rice bran addition ( $>50 \%$, compared to the control treatment). Generally, the addition of dietary fibre to meatballs aims to improve the nutritional value by enhancing satiety and reducing energy intake and, at the same time, increase the fibre consumption among consumers; starch typically contributes about $70-80 \%$ of the total carbohydrates in normal diets - a value deemed to be too high and thus unhealthy [35]. In chevon patties, for example, it was noted that $15-20 \%$ addition of oat bran enhanced the nutritional value with minimal composition and texture changes [36].

\subsection{Glycaemic Index (GI)}

The GI is a ranking of carbohydrates in foods from 0 to 100 depending on how fast and how much the specific carbohydrates increase blood sugar after being ingested [27]. Carbohydrate-based foods are categorised into three groups in which low-GI foods have a GI $<55$, and medium-GI food have a GI ranging between 55 and 70, while high-GI food products have a GI of more than 70 [37]. The calculation of GI values resulting from the replacement of tapioca starch by rice bran caused a decrease in the GI from 56.08 for $0 \%$ rice bran (100\% tapioca), down to 43.85 for $100 \%$ rice bran replacement. The treatment with $0 \%$ rice bran, which is also the traditional recipe for using tapioca in 'bakso', falls in the category of medium-GI foods, whereas all other treatments with rice bran are in the category of food with low GI. These results demonstrated that the inclusion of rice bran in the meatball recipe decreased the overall GI of the 'bakso' meatballs. This decrease in the GI of meatballs could be related to the high concentration of fibre in the rice bran. In agreement with these findings, it was demonstrated that the inclusion of dietary fibre in bread reduced its glycaemic index [38]. Moreover, Cheng et al. [39] suggested that rice bran might serve as a useful nutrient to ameliorate the glycaemic anomalies in type 2 diabetes.

\subsection{Physical Analysis}

Texture is an important factor dictating the sensory attributes in meatball products as well as palatability. The effects of various ratios of starch to rice bran on the textural properties of 'bakso' are shown in Table 4 . Consistency and firmness were $(p<0.05)$ affected by the ratio of starch to rice bran. Consistency had the highest score at $0 \%$ and lowest at $50 \%$, and the firmness had the highest score at $50 \%$ and lowest at $100 \%$ of rice bran in the ratio starch to rice bran. Shear force was not $(p>0.05)$ affected by the increased proportion of rice bran. The change in the textural profile of meatballs with rice bran, compared to the control, could be due to migration and loss of water. A similar observation was made by Ham et al. [40], who found changes in the textural profile of meatballs with the increase of rice bran; however, there was no significant difference in terms of cohesiveness. Additionally, the increase in fibre from the rice bran could have resulted in a decrease in cohesiveness. Adding bael (Aegle marmelos L.) pulp residue to goat meat nuggets (emulsions) was noted to decrease the hardiness, gumminess, and chewiness of the products [41]. Similarly, when full-fat soy pastes or textured soy granules were added to goat meat nuggets (the final product was an emulsion), replacing $15 \%$ of the goat 
meat, a decrease in the textural profile (shear force, hardness, springiness, gumminess, and chewiness) was observed-the decrease was contributed to both the soft texture of the soy paste and the increase in water content [42]. A similar decrease in texture attributes was noted by the same research team when soy proteins in the form of full-fat soy paste were added to goat meat patties [43]. The effect of the addition of soy proteins (as well as other additives such as liquid whole egg and fat) into goat patties was modelled, and it was shown that the acceptability of the baked patties decreased as the amount of soy increased [44] —a finding somewhat similar to that from this study with the addition of rice bran.

As pertaining to the colour of the cooked meatballs (Table 4), the yellowness increased with the addition of rice bran, whereas the redness decreased. These results are similar to other research, e.g., in meat products, the yellowness increased with the addition of fibre [23], and the redness was reported to decrease with the increased level of rice bran [45]. Furthermore, Kim et al. [45] demonstrated that the addition of $3 \%$ of rice bran in ground pork enhanced the yellowness values. Conversely, Ayhan [46] reported that the addition of cereal bran in meatballs had much lower yellowness than the control samples. Huang et al. [47], who studied the impacts of rice bran in meatballs, showed that the white index decreased with the addition of rice bran, in the present study there was no difference in this colour ordinate $\left(\mathrm{L}^{*}\right)$ between treatments (Table 4$)$. On the other hand, Das et al. [41] showed that with the addition of bael, the reflectance (lightness) and redness of the goat nuggets increased, whilst the yellowness remained the same. However, when full-fat soya paste was added to goat patties, there was an increase in the yellowness and a decrease in the redness of the final raw product [48].

Adding lower-valued, fibre-rich plant by-products has been known to improve the functional properties of goat meat patties/products [49-51]; for example, psyllium husks were shown to improve the functional quality of goat burger patties $[52,53]$.

\subsection{Consumers Sensory Evaluation}

Indonesian people (who had been living in Australia for more than 6 months) were targeted for this study because they are the typical target market for this meatball product in Indonesia. These consumers evaluated the new recipe of 'bakso', using goat meat instead of beef as the common ingredient and the additional rice bran to replace the tapioca as filler. The compositional results indicated that rice bran replacement of tapioca resulted in a 'bakso' that was healthier (higher protein and fibre contents and lower GI); however, the next question was 'Would people still be interested to eat such a bakso?' Consumer acceptability scores for parameters such as colour and odour were not affected by the substitution of the rice bran even up to $100 \%$ replacement. It was stated that substitution of cassava starches up to $100 \%$ with rice bran in beef meatballs had a significant effect on consumer acceptance in terms of colour attributes [2]. However, in this investigation, the 'overall', flavour, texture, and taste parameters did not differ when $0 \%$ or $25 \%$ of rice bran replaced tapioca, indicating that the latter was still acceptable to the consumers with most of the parameters lying within the 'like slightly' to 'like moderately' classification. It would seem as if a $25 \%$ rice bran replacement of tapioca is considered as optimum for use in a goat meatball. However, traditionally, 'bakso' is eaten with various sauces, and it is argued that if the meatballs had been served with different sauces, the different treatments' 'bakso' may have fallen into the higher classification of 'like very much' or even 'like extremely'.

\section{Conclusions}

Substitution of tapioca with rice bran in the production of a traditional Asian goat meatball, 'bakso', improved its nutritional quality with an increase in the protein and fibre contents, whilst the starch content was decreased. More importantly, the replacement of tapioca with rice bran resulted in a 'bakso' with a low GI, from a medium GI. The goat 'bakso' with rice bran was found to be acceptable to the Indonesian consumers, who used the score of 'like slightly' to 'like moderately' for all the attributes. Up to $25 \%$ substitution 
with rice bran was revealed to be acceptable by 40 Indonesian consumers. It is argued that if the rice bran 'bakso' were to be consumed in the traditional manner with sauces, this liking would move up the scale, and the consumers may not be able to distinguish between the different treatments; this warrants further research. Another aspect worthy of investigation is the cost implication of using rice bran, which is presently used as animal feed, in a food source such as 'bakso'.

As mentioned by Teixeira et al. [45], numerous goat meat products such as 'bakso' are part of the culture of various countries and have not yet been studied and characterised for the preservation of their recipes and origins; this paper is a start in describing the very popular and readily consumed (in Indonesia) 'bakso'.

Author Contributions: Conceptualisation, R.O.S. and L.C.H.; methodology, R.O.S., D.U. and L.C.H.; software, L.C.H.; validation, L.C.H.; formal analysis, R.O.S., D.U. and L.C.H.; investigation, R.O.S., M.M.B., D.U. and L.C.H.; resources, L.C.H.; data curation, R.O.S. and L.C.H.; writing-original draft preparation, R.O.S., M.M.B. and D.U.; writing—review and editing, J.J., E.S., A.A., H.E.S. and L.C.H.; visualisation, R.O.S. and L.C.H.; supervision, H.E.S. and L.C.H.; project administration, D.U.; funding acquisition, L.C.H. All authors have read and agreed to the published version of the manuscript.

Funding: This research was funded by the Centre for Nutrition and Food Sciences, Queensland Alliance for Agriculture and Food Innovation (QAAFI), The University of Queensland, Australia Award, Grant Number RIIS2059449.

Institutional Review Board Statement: The study was approved by Institutional Human Research Ethics Approval, The University of Queensland with Approval Number 2020001685 on 18 August 2020.

Informed Consent Statement: Informed consent was obtained from all subjects involved in the study.

Data Availability Statement: Data available from corresponding author.

Acknowledgments: We would like to take this opportunity and thank our statistical experts from the University of Stellenbosch, South Africa, who help and support the data analysis, for Peter Isherwood, Katherine Raymont, and Emma Hassall from The University of Queensland, Australia, for their technical support, and also members of University of Queensland Indonesian Student Association (UQISA) for their support.

Conflicts of Interest: The authors declare no conflict of interest.

\section{References}

1. Purnomo, H.; Rahardiyan, D. Review article: Indonesian traditional meatball. Int. Food Res. J. 2008, 15, 101-108. Available online: https:/ / www.researchgate.net/publication/279548228_Indonesian_traditional_meatball. (accessed on 8 June 2021).

2. Kartikawati, M.; Purnomo, H. Improving meatball quality using different varieties of rice bran as natural antioxidant. Food Res. 2019, 3, 79-85. [CrossRef]

3. Meat and Livestock Australia. Market Snapshot: Goat Meat, Meat \& Livestock Australia. 2018. Available online: https: //www.mla.com.au/globalassets/mla-corporate/prices--markets/documents/os-markets/red-meat-market-snapshots / mlaglobal-snapshot-goat-2017.pdf (accessed on 8 June 2021).

4. Ivanovic, S.; Pavlovic, I.; Pisinov, B. The quality of goat meat and it's impact on human health. Biotechnol. Anim. Husb. 2016, 32, 111-122. [CrossRef]

5. USDA. Nutrient Database for Standard Reference, Release 14; U.S. Government Printing Office: Washington, DC, USA, 2001.

6. Ijioma, B.C.; Ihediohanma, N.C.; Okafor, D.C.; Ofoedu, C.E.; Ojimba, C.N. Physical, chemical, and sensory attributes of tapioca grits from different cassava varieties. Asian J. Agric. Food Sci. 2016, 4, 46-53. [CrossRef]

7. Masrul, M.; Nindrea, R.D. Dietary fibre protective against colorectal cancer patients in Asia: A Meta-Analysis. Open Access Maced. J. Med. Sci. 2019, 7, 1723-1727. [CrossRef]

8. World Health Organization. Obesity and Overweight. 2020. Available online: https://www.who.int/news-room/fact-sheets/ detail/obesity-and-overweight (accessed on 8 June 2021).

9. Indonesian Ministry of Health. Hasil Utama Riskesdas 2018-Kementerian Kesehatan Badan Penelitian dan Pengembangan Kesehatan. 2018. Available online: https://www.kemkes.go.id/resources/download/info-terkini/hasil-riskesdas-2018.pdf (accessed on 8 June 2021).

10. AIHW. Overweight \& Obesity. 2020. Available online: https://www.aihw.gov.au/reports-data/behaviours-risk-factors/ overweight-obesity / overview (accessed on 8 June 2021). 
11. Foster-powell, K.; Susanna, H.A.; Brand-Miller, J.C. International table of glycemic index and glycemic load values: 2002. Am. J. Clin. Nutr. 2002, 76, 5-56. [CrossRef]

12. Brand-Miller, J.; Pang, E.; Bramall, L. Rice: A high or low glycemic index food? Am. J. Clin. Nutr. 1992, 56, 1034-1036. [CrossRef]

13. Fernando, B. Rice as a source of fibre. Rice Res. Open Access 2013, 1, 1-4. [CrossRef]

14. Statistics Indonesia. Harvested Area and Rice Production in Indonesia; BPS, Statistics Indonesia: Jakarta, Indonesia, 2008.

15. Laksmi, A.K.; Budijanto, S. Development of rice bran based rice analog. In Proceedings of the 23rd Tri-University International Joint Seminar and Symposium, Bogor Agricultural University, Bogor, Indonesia, 24-28 October 2016.

16. Kahlon, T.S. Rice bran: Production, composition, functionality and food applications, physiological benefits. In Fiber Ingredients: Food Applications and Health Benefits; Cho, S.S., Samuel, P., Eds.; CRC Press: Boca Raton, FL, USA, 2009. [CrossRef]

17. Alauddina, M.; Islama, J.; Shirakawa, H.; Kosekib, T.; Komaia, A.; Komaia, M. Rice Bran as a Functional Food: An Overview of the Conversion of Rice Bran into a Superfood/Functional Food (Chapter 14). 2017. Available online: https: //www.intechopen.com/books/superfood-and-functional-food-an-overview-of-their-processing-and-utilization/rice-branas-a-functional-food-an-overview-of-the-conversion-of-rice-bran-into-a-superfood-functiona (accessed on 8 June 2021). [CrossRef]

18. AOAC International. Loss on drying (moisture) at $95-100{ }^{\circ} \mathrm{C}$ for feeds. In Official Methods of Analysis, 17th ed.; AOAC Official Method 934.0; Association of Official Analytical Chemists Inc.: Arlington, VA, USA, 2002.

19. AOAC International. Analytical Chemists Inc. Ash of Animal Feed. In Official Methods of Analysis, 17th ed.; AOAC Official Method 934.0; Association of Official Analytical Chemists Inc.: Arlington, VA, USA, 2002. [CrossRef]

20. McCleary, B.; Gibson, T.; Mugford, D. Measurement of total starch in cereal products by amyloglucosidase- $\alpha$-amylase method: Collaborative study. J. AOAC Int. 1997, 80, 571-579. [CrossRef]

21. Lee, C.M.; Trevino, B.; Chaiyawat, M. A simple, rapid solvent $\left(\mathrm{CHCl}_{3}-\mathrm{MeOH}\right)$ extraction method for determination of total lipids in fish tissue. J. AOAC Int. 1996, 79, 487-492. [CrossRef] [PubMed]

22. Zayas, J.F.; Lin, C.S. Quality characteristics of frankfurters containing corn germ protein. J. Food Sci. 1998, 53, 1587-1591. [CrossRef]

23. Aukkanit, N.; Kemngoen, T.; Ponharn, N. Utilization of corn silk in low fat meatballs and its characteristics. Proced. Soc. Behav. Sci. 2015, 197, 1403-1410. [CrossRef]

24. Huda, N.; Shen, Y.H.; Huey, Y.L. Proximate composition, colour, texture profile of Malaysian chicken balls. Pak. J. Nutr. 2009, 8, 1555-1558. [CrossRef]

25. Erdem, N.; Babaoğlu, A.S.; Poçan, H.B.; Karakaya, M. The effect of transglutaminase on some quality properties of beef, chicken, and turkey meatballs. J. Food Process. Preserv. 2020, 44, 1-8. [CrossRef]

26. Khan, I.A.; Xu, W.; Wang, D.; Yun, A.; Khan, A.; Zongshuai, Z.; Ijaz, M.U.; Yiqun, C.; Hussain, M.; Huang, M. Antioxidant potential of chrysanthemum morifolium flower extract on lipid and protein oxidation in goat meat patties during refrigerated storage. J. Food Sci. 2020, 85, 618-627. [CrossRef] [PubMed]

27. Dodd, H.; Williams, S.; Brown, R.; Venn, B. Calculating meal glycemic index by using measured and published food values compared with directly measured meal glycemic index. Am. J. Clin. Nutr. 2011, 94, 992-996. [CrossRef] [PubMed]

28. Foodstruct. Nutrition, Glycemic Index, Calories and Serving Size. 2020. Available online: https:/ / foodstruct.com (accessed on 8 June 2021).

29. Eka, K. Comparative Study of Glycemic Index Between Agar and Jelly. Undergraduate Thesis, Universitas Airlangga, Surabaya, Jawa Timur, Indonezia, 2014.

30. Aktas, K.; Akin, N. Influence of rice bran and corn bran addition on the selected properties of tarhana, a fermented cereal based food product. LWT-Food Sci. Technol. 2020, 129, 109574. [CrossRef]

31. Qwele, K.; Hugo, A.; Oyedemi, S.O.; Moyo, B.; Muchenje, V. Chemical composition, fatty acid content and antioxidant potential of meat from goats supplemented with Moringa (Moringa oleifera) leaves, sunflower cake and grass hay. Meat Sci. 2013, 93, 455-462. [CrossRef] [PubMed]

32. Webb, E.C.; Casey, N.H.; Simela, L. Goat meat quality. Small Rumin. 2005, 60, 153-166. [CrossRef]

33. Choi, Y.S.; Jeong, J.Y.; Choi, J.; Han, D.J.; Kim, H.; Lee, M.; Kim, H.; Paik, H.; Kim, C. Effects of dietary fiber from rice bran on the quality characteristics of emulsion-type sausages. Korean, J. Food Sci. Anim. Resour. 2008, 28, 14-20. [CrossRef]

34. Schönfeldt, H.C.; Naudé, R.T.; Bok, W.; Heerden, S.M.; Sowden, L.; Boshoff, E. Cooking-and juiciness-related quality characteristics of goat and sheep meat. Meat Sci. 1993, 34, 381-394. [CrossRef]

35. Eleazu, C.O. The concept of low glycemic index and glycemic load foods as panacea for type 2 diabetes mellitus; prospects, challenges and solutions. Afr. Health Sci. 2016, 16, 468-479. [CrossRef]

36. Dawkins, N.L.; Phelps, O.; McMillin, K.W.; Forrester, I.T. Composition and physicochemical properties of chevon patties containing oat bran. J. Food Sci. 1999, 64, 597-600. [CrossRef]

37. QLD Health. Glycaemic Index of Foods. 2014. Available online: https://www.health.qld.gov.au/_data/assets/pdf_file/0026/1 43567 / paeds_gi.pdf (accessed on 8 June 2021).

38. Scazzina, F.; Siebenhandl-Ehn, S.; Pellegrini, N. The effect of dietary fiber on reducing the glycemic index of bread. Br. J. Nutr. 2013, 109, 1163-1174. [CrossRef] [PubMed]

39. Cheng, H.H.; Huang, H.Y.; Chen, Y.Y.; Huang, C.L.; Chang, C.J.; Chen, H.L.; Lai, M.H. Ameliorative effects of stabilized rice bran on type 2 diabetes patients. Ann. Nutr. Metab. 2010, 56, 45-51. [CrossRef] 
40. Ham, Y.K.; Hwang, K.E.; Song, D.H.; Choi, J.H.; Choi, Y.S.; Kim, H.W. Relationship between the antioxidant capacity of soy sauces and its impact on lipid oxidation of beef patties. Meat Sci. 2019, 158, 107907. [CrossRef] [PubMed]

41. Das, A.K.; Rajkumar, V.; Verma, A.K. Bael pulp residue as a new source of antioxidant dietary fiber in goat meat nuggets. J. Food Proc. Preserv. 2014, 39, 1626-1635. [CrossRef]

42. Das, A.K.; Anjaneyulu, A.S.R.; Gadekar, Y.P.; Singh, R.P.; Pragati, H. Effect of full-fat soy paste and textured soy granules on quality and shelf-life of goat meat nuggets in frozen storage. Meat Sci. 2008, 80, 607-614. [CrossRef] [PubMed]

43. Das, A.K.; Anjaneyulu, A.S.R.; Kondaiah, N. Development of reduced beany flavour full-fat soy paste for comminuted meat products. J. Food Sci. 2006, 71, S395-S400. [CrossRef]

44. Gujral, H.S.; Kaur, A.; Singh, N.; Sodhi, N.S. Effect of liquid whole egg, fat and textured soy protein on the textural and cooking properties of raw and baked patties from goat meat. J. Food Eng. 2002, 53, 377-385. [CrossRef]

45. Kim, H.W.; Choi, Y.S.; Choi, J.H.; Han, D.J.; Kim, H.Y.; Hwang, K.E.; Song, D.H.; Kim, C.J. Effects of rice bran fiber on changes in the quality characteristics of raw ground pork during chilled storage. Korean, J. Food Sci. Anim. Resour. 2011, 31, $339-348$. [CrossRef]

46. Ayhan Duran, Ö.Ö.Ö. Production of low-fat high-fiber meatballs. J. Sci. Eng. Res. 2018, 5, 150-155. Available online: http:/ / oaji.net/articles/2019/4834-1563171754.pdf. (accessed on 8 June 2021).

47. Huang, S.C.; Shiau, C.Y.; Liu, T.E.; Chu, C.L.; Hwang, D.F. Effects of rice bran on sensory and physico-chemical properties of emulsified pork meatballs. Meat Sci. 2005, 70, 613-619. [CrossRef] [PubMed]

48. Das, A.K.; Anjaneyulu, A.S.R.; Run, K.; Kondaiah, N. Physicochemical, textural, sensory characteristics and storage stability of goat meat patties extended with full-fat soy paste and soy granules. Int. J. Food Sci. Techn. 2008, 43, 383-392. [CrossRef]

49. Teixeira, A.; Silva, S.; Guedes, C.; Rodrigues, S. Sheep and goat meat processed products quality: A review. Foods 2021, 9, 960. [CrossRef]

50. Teixeira, A.; Silva, S.; Guedes, C.; Rodrigues, S. Chapter six-Advances in Sheep and goat meat products research. Adv. Food Nutr. Res. 2019, 87, 305-370. [CrossRef]

51. Das, A.K.; Nanda, P.K.; Madane, P.; Biswas, S.; Das, A.; Zhang, W.; Lorenzo, J.M. A comprehensive review on antioxidant dietary fiber enriched meat-based functional foods. Trends Food Sci. Technol. 2020, 99, 323-336. [CrossRef]

52. Kauser, T.; Kauser, M.A.; Azad, Z.R.A.A. Improving the quality and shelf life of goat meat patties with herb and husk incorporation. Biochem. Cell. Arch. 2018, 18, 1569-1576.

53. Kauser, T.; Kauser, M.A.; Khan, S.; Haque, S. Optimum additive composition to minimize fat in functional goat meat nuggets: A healthy red meat functional food. Processes 2021, 9, 475. [CrossRef] 